\title{
GROWTH RATE AND CONDITION OF VIMBA, VIMBA VIMBA (ACTINOPTERYGII: CYPRINIFORMES: CYPRINIDAE), A SPECIES UNDER RESTITUTION IN THE ODRA RIVER ESTUARY
}

\author{
Przemysław CZERNIEJEWSKI*, Agnieszka RYBCZYK, Adam TAŃSKI, \\ Sławomir KESZKA, and Artur ANTOSZEK
}

Faculty of Food Sciences and Fisheries, West Pomeranian University of Technology in Szczecin, Poland

Czerniejewski P., Rybczyk A., Tański A., Keszka S., Antoszek A. 2011. Growth rate and condition of vimba, Vimba vimba (Actinopterygii: Cypriniformes: Cyprinidae), a species under restitution in the Odra River estuary. Acta Ichthyol. Piscat. 41 (3): 215-222.

\begin{abstract}
Background. The majority of European populations of vimba, Vimba vimba (L.), have been classified into increasing categories of conservation status while Polish populations of this fish are classified as CR (critically endangered) and in fact they are facing extinction. In many rivers in Poland, including the Odra River, restitution efforts of vimba have been undertaken. Monitoring some biological parameters of the population such as the rate of growth (increase in mass and length), age structure, sex structure, and condition nay help to evaluate the success rate of the restitution efforts.

Materials and methods. In total, 210 individuals of vimba, caught in the waters of the southern part of the Odra River estuary, mainly in Lake Dąbie, between 28 May 2007 and 30 June 2008 were studied as to their age, condition, rate of growth in mass and length. Making use of the linear R-L dependence, the back calculations were made according to the Rosa Lee procedure with a standard of $20 \mathrm{~mm}$. Results were approximated by 5 mathematical models of growth proposed by von Bertalanffy, Ford-Walford, Gompertz, and based on second degree polynomial function and modified power function. Increase in mass was described by a modified von Bertalanffy equation. The condition of the fish was described by the Fulton $(K)$ and Le Cren $\left(L_{\mathrm{c}}\right)$ formulae.

Results. Females dominated in the material studied, they constituted over $61 \%$ of all individuals. In the age structure groups, females were most often found in groups: $10+(13.33 \%), 9+$, and $11+(12.86 \%$ each). Males were found in the greatest number among 5-, 6-, and 7-year-old fish (4+, 5+, and 6+, respectively). The mean standard length and mass of the vimba fish studied were $306.33 \mathrm{~mm}$ and $286.02 \mathrm{~g}$, respectively. The annual increase in length of the fish approximated $20 \mathrm{~mm}$, being the most intense in the first two years of life (23-24 mm). Fulton and Le Cren coefficients of condition were 0.93 and 1.64 and the ranges of these values were $0.69-1.47$ and $1.15-2.60$, respectively.

Conclusion. Analysis of back readings and empirical results proved that the growth of vimba was best approximated by the von Bertalanffy model. Comparative analysis of condition coefficients of the population of vimba in the Odra River estuary and other populations showed that the condition of analysed vimba population in individual years of live was lower.
\end{abstract}

Keywords: Odra River, Oder River, vimba, restitution, growth rate, condition coefficient

\section{INTRODUCTION}

Vimba, Vimba vimba (L.) (known also as vimba bream, zanthe, or zarte), occurs in the catchment areas of the Baltic-, North-, Black-, and Caspian seas. In the majority of waters it is classified as critically endangered (Lelek 1987). In Polish waters it has been caught mainly in the Gulf of Gdańsk, where vimba used to be a major component of the ichthyofauna, constituting as much as $40 \%$ of the biomass of the freshwater fish (Bontemps 1971, Wiśniewolski et al. 2008). The earliest archaeological records of this fish, being caught by people, come from medieval times (Chełkowski and Filipiak 2000, Makowiecki 2003).

The population of vimba, living in the Odra (Oder) River estuary, belongs to the migrating-anadromous form. The spawning season of this species takes place from the middle of May to the end of June, in well aerated, fast-lowing rivers and on gravel-stone river beds (Bontemps 1971). Juvenile fish migrate downstream to marine foraging areas. Before approaching sexual maturity they start their upstream journey to reach their spawning grounds. On their way, they gradually reach sexual maturity. In the sys- 
tem of the lower Odra River tributaries, this species reached sexual maturity at the age of 8-9 years (Pęczalska and Kraczkiewicz 1973). In the first decade after the second world war, vimba used to be abundant in the lower Odra River as illustrated by the amounts of this fish caught in 1953-16.7 t, 1954-32.4 t, 1955-18.7 t, and in 1956-25.3 t (Bontemps 1955). According to Wiśniewolski (1987), till as late as the mid 1970s this fish had been an important species for the fisheries economy and, according to the statistics of the Fishermen Cooperative in Gryfino (unpublished), it suddenly disappeared in 1975. Within 1958-1970 the annual catch (and landings) of vimba in the Szczecin Lagoon, varied from 3.5 to $27 \mathrm{t}$ (Pęczalska and Kraczkiewicz 1973). As it is evident from the data published by Psuty-Lipska and Garbacik-Wesołowska (1998) vimba sporadically occurred in the Szczecin Lagoon. Vimba was classified as one of the 37 most endangered species and in Poland it was given the status of critically endangered species (CR) (Witkowski et al. 2009). In Germany and Slovenia it was classified as endangered (EN), in the Czech Republic and Austria it is vulnerable (VU), and only in Turkey it is of the least concern (Kempter 2010). In Poland vimba, along with Atlantic sturgeon, salmon, and sea trout, has been assigned to the project of migratory fish restitution (Sych 1996).

The status of vimba should be monitored by checking biological and population traits of the species from the Odra River estuary and comparing them with the data from other European regions. The results are also useful for evaluation of the success of vimba restitution in the Odra River drainage area.

\section{MATERIAL AND METHODS}

The material examined were vimba caught in the southern part of the Odra River estuary (mainly from Lake Dąbie) in the period between the 28 May 2007 and 30 June 2008, with the fyke net. In total, 210 vimba were studied.

The fish were measured, to the nearest $0.1 \mathrm{~mm}$, using a calliper and the data were fed to a PC unit. Subsequently, they were weighed on an Axis 2000 balance to the nearest $0.1 \mathrm{~g}$. The fish condition and the growth rate (in length and mass) were determined. On the basis of the results of measurements the correlation between the standard length and mass of the fish was approximated by a power function (Szypuła and Rybczyk 2001):

where:

$$
W=k L^{n}
$$

$W=$ total mass of the fish $[\mathrm{g}]$;

$L=$ standard length $[\mathrm{mm}]$;

$k$ and $n=$ constant parameters obtained based on empirical data.

The condition of the fish was described with the use of the Fulton $(K)$ and Le Cren $\left(L_{\mathrm{c}}\right)$ formula (RitterbuschNauwerck 1995, Bolger and Connolly 1989). The length and mass growth rate were estimated based on scales.. The scales were collected following the method of Bontemps (1971) from the area between the first ray of the dorsal fin and the lateral line, then the scales were cleaned of mucus in a water solution of ammonia and then preparations were made. The age was read based on the annual rings observed, magnified $17 \times$, under a transmitted-light microfilm projector. For each fish this procedure was repeated on 3 or 4 scales.

Making use of the linear relation between $R$ (scale radius) and $L$ (fish length) the back calculations were made in the Rosa Lee variant with a standard of $20 \mathrm{~mm}$, which is the length at which the scale starts to form in vimba (Heese 2000). At the next stage an attempt was made to approximate the empirical data with a few mathematical models of growth: von Bertalanffy, Ford-Walford, second degree polynomial, and modified power function (Szypuła and Rybczyk 2001). The growth of vimba mass was found to be best described by the modified von Bertalanffy formula.

The numbers, as well as the cumulative mass of vimba caught in individual months of the year was determined. The results were subjected to statistical analysis (program Microsoft Excel ${ }^{\circledR}$, Statistica ${ }^{\circledR} 6.0$ ) to find the arithmetic means and ranges of values of particular traits. Verification of the hypothesis of the equality of means was preceded by verification of normality of distribution of a given trait (Shapiro-Wilk test and Levene test for homogeneity of variance were applied). Significance of differences was verified by Scheffe test $(P<0.05)$ and variance analysis (for many samples) (Stanisz 2000). Correlations between variables were checked by regression analysis. The quality of empirical data approximation by particular functions was evaluated on the basis of the correlation coefficient $(R)$ or determination coefficient $\left(R^{2}\right)$. Significance of the correlation coefficient was evaluated by Student's $t$-test (Sokal and Rohlf 1995).

\section{RESULTS}

In the course of the presently reported study (May 2007-June 2008) the majority of fish (100) were caught in June (constituting 41.62\%), then in May $(12.86 \%)$, and in October $(12.38 \%)$. The lowest number of vimba was caught in November $(3.33 \%)$, April $(2.38 \%)$ and March (0.48\%) (Fig. 1). Among the 210

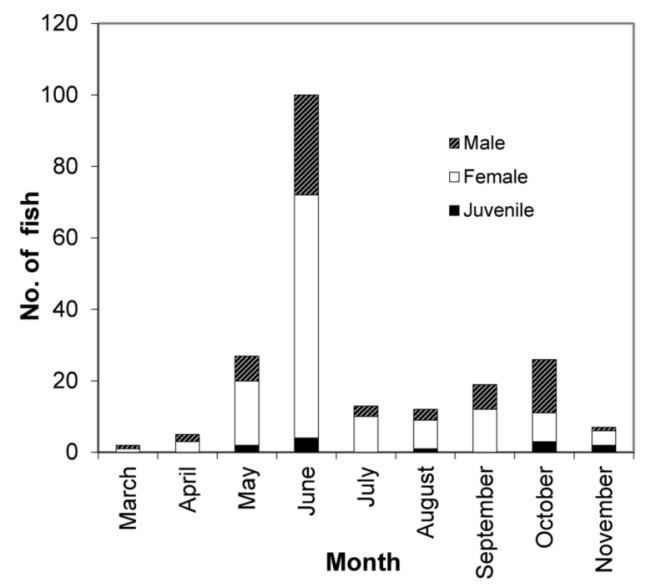

Fig. 1. Seasonal changes in the number of Vimba vimba, caught in the Odra river estuary 
vimba studied, there were 130 females $(61.90 \%)$, while only 68 males (32.28\%). Only 12 individuals (5.71\%) were sexually immature. In terms of the age, the three dominant age groups were 9- (16.67\%), 10- (13.33\%), and 11 -year olds $(13.33 \%)(8+, 9+$, and $10+$, respectively) Females were most abundant in groups: $10+(13.33 \%)$, $9+$, and $11+(12.86 \%$ in each group $)$. Males were found in the greatest number in groups: of $5+, 6+$, and $7+$, while in the lowest number - among the oldest fish $(10+$ and $11+)$. Sexually immature individuals were found in two age groups: $3+(1.90 \%)$ and $4+(3.81 \%)$ (Fig. 2$)$. The mean standard length and mean individual mass of the fish examined were $306.33 \mathrm{~mm}$ and $286.02 \mathrm{~g}$, respectively. Statistically significant differences in these parameters were found between males and females. Females had statistically greater mean length and mass than males and juvenile individuals (Table 1). To analyse the contribution of fish of particular length they were classified into 12 length classes, set at intervals of $20 \mathrm{~mm}$, from 170 to $410 \mathrm{~mm}$. The highest number of fish (44 individuals) represented the class of $330.1-350 \mathrm{~mm}(20.95 \%)$, while the lowest number of fish-1 individual $(0.48 \%)$ and 12 individuals $(0.95 \%)$-represented the classes of $390.1-410 \mathrm{~mm}$ and $170.1-190.0 \mathrm{~mm}$, respectively. Analysis of the contribution of males and females in particular length classes showed that females were found in 10 classes, in the highest number in $330.1-350.0 \mathrm{~mm}$ (18.1\%) and 350.1-370.0 $\mathrm{mm}(15.71 \%)$. Males were found in the greatest number of 13 individuals in the class of 210.1-230.0 mm, while in the lowest number of 1 individual in the classes of 170.0-190.0 $\mathrm{mm}$ and 350.1-370.0 $\mathrm{mm}$. Juvenile individuals were found in the three smallest classes of length and their contribution in the whole sample was $5.71 \%$ (Fig. 3). The correlations between standard length and individual mass of the vimba from the Odra River estuary for particular sex groups were described by the following formulae:

- females: $y=0.0001 \times 2.5855$,

- males: $y=0.00002 x 2.8858$,

- juvenile individuals: $y=0.00005 \times 2.6848$.

The above formulae and statistically significant values of the determination coefficients $R^{2}$ of the range $0.7888-0.8674$ (at $P<0.05$ ) indicate a good fit of the empirical points to the regression line.

Table 2 presents the rate of growth of vimba body length in particular years of live determined by the Rosa

Mean standard length (SL) and individual mass of Vimba vimba caught in the Odra River estuary

\begin{tabular}{lcccc}
\hline & \multicolumn{2}{c}{ Standard length [mm] } & \multicolumn{2}{c}{ Individual mass [g] } \\
\cline { 2 - 5 } & Mean & Range & Mean & Range \\
\hline Total & 306.33 & $175.0-395.0$ & 286.02 & $47.0-781.0$ \\
Females & $331.05^{\mathrm{a}}$ & $214.0-395.0$ & $342.49^{\mathrm{a}}$ & $98.0-781.0$ \\
Males & $276.19^{\mathrm{b}}$ & $183.0-358.0$ & $276.19^{\mathrm{b}}$ & $50.0-452.0$ \\
Juveniles & $209.33^{\mathrm{c}}$ & $175.0-224.0$ & $77.67^{\mathrm{c}}$ & $47.0-97.0$ \\
\hline
\end{tabular}

Values with the same superscript are significantly different $(P>0.05)$.

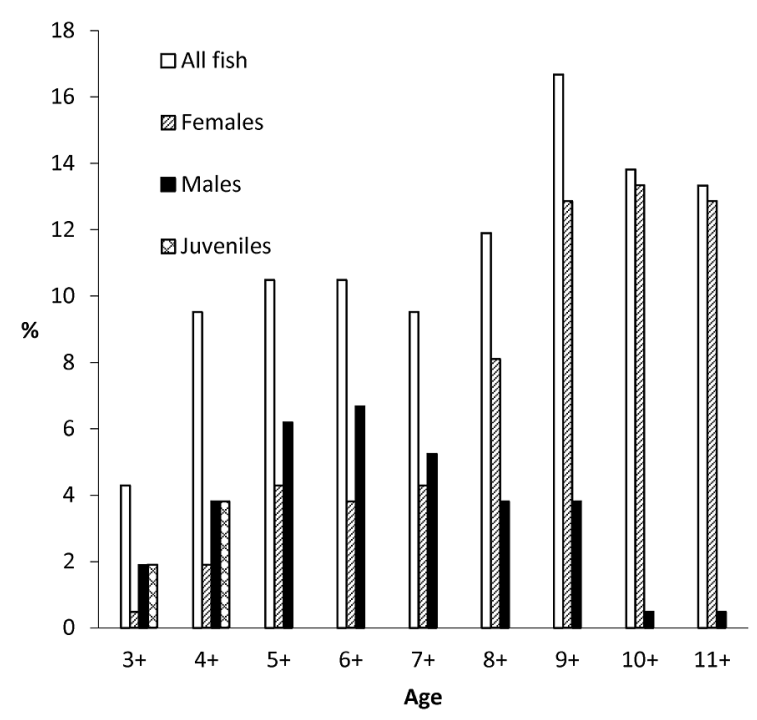

Fig. 2. Age structure of Vimba vimba, caught in the Odra River estuary

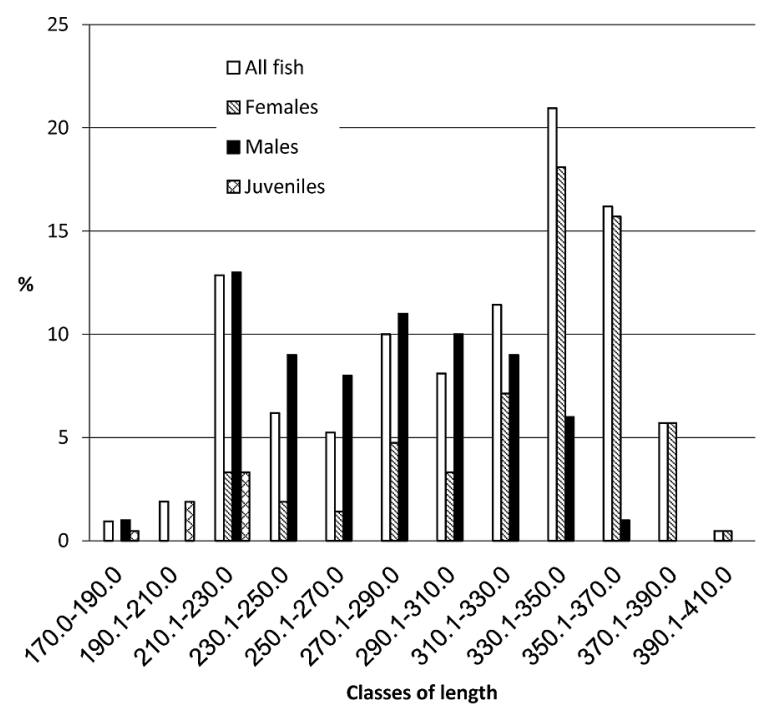

Fig. 3. Length structure of the Vimba vimba, caught in the Odra River estuary

Lee procedure of back calculations. In the fish studied the annual increment in length was similar and close to $20 \mathrm{~mm}$, but in the first two years of live this increase was the greatest, reaching 23-24 mm. In the last years of age the annual increase in length was below $20 \mathrm{~mm}$. Besides the empirical data and back readings, Table 2 also presents the results predicted by the models of growth considered: Ford-Walford, von Bertalanffy, Gompertz, second degree polynomial, and power function. The best fit to the back read results was found for the von Bertalanffy model. The mean absolute difference was $1.35 \mathrm{~mm}$ with reference to the results of back calculations. The poorest fit was obtained for the Gompertz model for which the mean absolute difference was over $16 \mathrm{~mm}$.

Figure 4 presents the rate of growth in mass calculated from the modified von Bertalanffy function:

$$
W_{t}=342.04\left[1-\mathrm{e}^{-0.24045(\mathrm{t}+0.748551)}\right]^{2.83726}
$$


The mean values of Fulton $(K)$ and Le Cren $\left(L_{\mathrm{C}}\right)$ coefficients was 0.93 and 1.64, respectively, but their values were statistically significantly lower for females than for males. For females the mean Fulton coefficient was 0.92 and Le Cren coefficient was 1.64, while for males the respective values were 0.97 and 1.68 . The lowest values of the Fulton and Le Cren coefficients were found for juvenile fish ( 0.84 and 1.39 , respectively). It should be mentioned that the Fulton and Le Cren coefficients varied over rather large ranges: $0.69-1.47$ and 1.15-2.60, respectively. The highest value of Fulton coefficient was obtained for the fish aged $6+$, while the highest Le Cren coefficient - for the fish aged $10+$ and $11+($ Table 3$)$.

\section{DISCUSSION}

In the beginning of the 20th century vimba was one of the most economically valuable species, especially in the waters of lagoons, bays or near estuaries of large rivers. According to Bontemps (1971), in the catchment from coastal water the fish of this species made $35 \%-40 \%$ of the total amount of the fresh water fish. They were mostly caught in the Gulf of Gdańsk, the Pomeranian Bay, the Szczecin Lagoon, and the Odra River. In the first years after the second world war vimba was abundant in the lower Odra River. The fish was caught in the Warta River and its tributaries and in almost whole catchment area of the Odra River (Witkowski et al. 2004). Since the early 1970 s, the number of vimba in catches has been drastically declining (Wiśniewolski 1987) and since 1975 this species has not been reported in commercial catches, according to the statistics of the Fishermen Cooperative "Regalica" in Gryfino (unpublished), exploiting the stretch of the lower Odra River from the Myśla River mouth in the south to the bridge on highway A6 in the north.

The biomass of captured (and landed) vimba from the lower Odra River, was lower than that reported from the Pomeranian Bay and the Szczecin Lagoon. In the beginning of the 1950s, the cumulative mass of landed vimba varied from 14.3 to $24.6 \mathrm{t}$ in the Pomeranian Bay and from

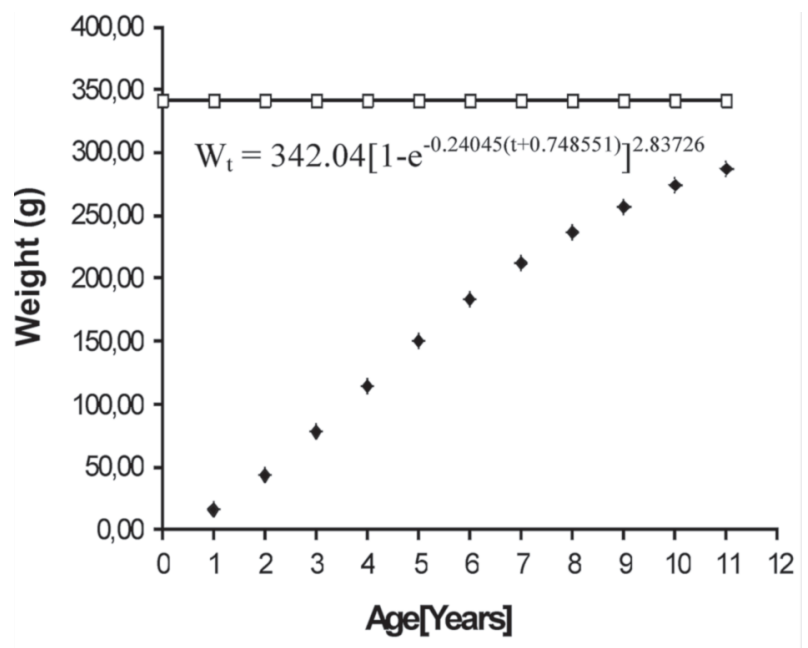

Fig. 4. The rate of growth of mass of Vimba vimba, caught in the Odra River estuary, approximated by the modified von Bertalanffy formula

9.0 to $19.9 \mathrm{t}$ in the Szczecin Lagoon, while in the Odra River and the Warta River it ranged from 7.7 to $12.5 \mathrm{t}$ (Bontemps 1971). In subsequent years also in the abovementioned bodies of water the amount of vimba significantly decreased. According to Pęczalska and Kraczkiewicz (1973) in the Szczecin Lagoon the annual catch of vimba, within 1958-1970, varied from 3.5 to 27 tons, while in 1987 it amounted to $441 \mathrm{~kg}$, and finally from 1989 vimba disappeared altogether from the catch statistics. In response to this situation a project of restitution of this species has been launched and since 2000 the stocking of this species has been performed in the waters of the Odra River drainage (Kleszcz et al. 2001). As a result the numbers of vimba caught in the Odra River estuary increased. In the Odra River estuary the vimba has still been considered an endangered species (Witkowski et al. 2009) although the increase in its population has been documented by a growing number of vimba caught within 2007-2008. The highest number of vimba in the Odra River estuary is caught

The rate of growth established for Vimba vimba, caught in the Odra River estuary,

Table 2 according to Rosa-Lee procedure and approximated by different models of growth [mm]

\begin{tabular}{|c|c|c|c|c|c|c|c|c|c|c|c|c|c|}
\hline \multirow{2}{*}{ Age group } & \multicolumn{7}{|c|}{ Method } & \multicolumn{6}{|c|}{ Mean absolute difference } \\
\hline & RL (1) & $\mathrm{ED}(2)$ & FW (3) & $\mathrm{vB}(4)$ & GP (5) & SDP (6) & $\mathrm{PF}(7)$ & {$[1-2]$} & {$[1-3]$} & {$[1-4]$} & {$[1-5]$} & {$[1-6]$} & [1-7] \\
\hline I & 95 & - & 62 & 93 & 99 & 68 & 92 & - & 33.10 & 2.22 & 3.57 & 1.53 & 3.41 \\
\hline II & 118 & - & 113 & 118 & 125 & 103 & 119 & - & 5.15 & 0.32 & 6.67 & 14.79 & 0.90 \\
\hline III & 142 & - & 153 & 142 & 151 & 135 & 143 & - & 11.95 & 0.89 & 9.21 & 6.22 & 1.82 \\
\hline IV & 164 & 183 & 186 & 166 & 177 & 165 & 167 & 18.64 & 21.93 & 1.39 & 12.14 & 0.52 & 2.10 \\
\hline V & 188 & 204 & 213 & 188 & 201 & 192 & 189 & 16.45 & 25.05 & 0.60 & 13.48 & 4.20 & 0.89 \\
\hline VI & 210 & 233 & 234 & 210 & 225 & 217 & 210 & 22.55 & 24.19 & 0.23 & 14.37 & 0.12 & 0.08 \\
\hline VII & 230 & 249 & 252 & 232 & 246 & 239 & 231 & 19.06 & 21.85 & 1.79 & 15.98 & 8.90 & 1.32 \\
\hline VIII & 253 & 265 & 266 & 252 & 265 & 258 & 252 & 11.37 & 12.52 & 0.97 & 11.85 & 1.09 & 1.57 \\
\hline IX & 275 & 290 & 277 & 272 & 282 & 275 & 272 & 14.59 & 1.90 & 2.99 & 7.00 & 2.95 & 3.49 \\
\hline$X$ & 293 & 307 & 286 & 291 & 297 & 290 & 291 & 14.15 & 6.49 & 1.23 & 4.50 & 1.03 & 1.37 \\
\hline XI & 308 & 319 & 294 & 310 & 310 & 302 & 311 & 11.23 & 14.39 & 2.21 & 2.34 & 5.96 & 2.73 \\
\hline \multicolumn{8}{|c|}{ Mean absolute difference } & 16.01 & 16.23 & 1.35 & 9.19 & 4.30 & 1.79 \\
\hline
\end{tabular}

$\mathrm{RL}=$ Rosa Lee, $\mathrm{ED}=$ empirical data, $\mathrm{FW}=$ Ford-Walford, $\mathrm{vB}=$ von Bertalanffy, $\mathrm{GP}=$ Gompertz, $\mathrm{SDP}=$ second degree polynomial, $\mathrm{PF}=$ power function. 
from May to October, with a clear maximum in June. The greatest biomass of vimba caught in river estuaries was noted during the spawning migration. Bontemps (1971) reported that in the Vistula Lagoon vimba was caught mainly in April and May, while in the Szczecin Lagoon and the Pomeranian Bay - from April to December. Pęczalska and Kraczkiewicz (1973) claimed that in the Szczecin Lagoon the greatest biomass of vimba was caught in autumn, while Raczyński and Keszka (2007) caught the greatest biomass of vimba in November and April.

As far as the sex structure is concerned, at present, in the spawning areas in the Odra River estuary the dominant presence of females $(61.90 \%)$ was observed. Pęczalska and Kraczkiewicz (1973), as well as Raczyński and Keszka (2007) also reported more females than males. The observation of a greater contribution of females in the Odra River estuary is rather exceptional as usually in rivers more males are found. Higher numbers of males were reported from the rivers Tarnawa (Suhanova et al. 1970) and Dyje (Lusk et al. 2005), from the Curonian Lagoon (Repecka 2003), and in the beginning of the 1970s also in the Rega River (Trzebiatowski and Narożański 1973). A dominant contribution of males reported by the above authors was probably related to the fact that the fish they studied were caught during the spawning season. According to Suhanova et al. (1970) and Bontemps (1971), females leave the spawning area swimming down the river directly after spawning while males remain longer in the area and are run a greater risk of being caught.

The standard length of vimba caught in the Odra River estuary and studied by us varied from 175 to $395 \mathrm{~mm}$ for

Mean values of condition coefficients (Cc) characterising Vimba vimba, caught in the Odra River

Table 3 estuary and ranges of their changes

\begin{tabular}{|c|c|c|c|c|c|}
\hline \multirow{2}{*}{ Age } & \multirow{2}{*}{ Sex } & \multicolumn{2}{|c|}{ Fulton } & \multicolumn{2}{|c|}{ Le Cren } \\
\hline & & Mean \pm SD & Range & Mean \pm SD & Range \\
\hline \multirow{4}{*}{$3+$} & Females & 0.96 & $0.96-0.96$ & 1.59 & $1.59-1.59$ \\
\hline & Males & $0.96^{\mathrm{a}} \pm 0.12$ & $0.82-1.07$ & $1.59^{\mathrm{a}} \pm 0.22$ & $1.32-1.79$ \\
\hline & Juveniles & $0.83^{b} \pm 0.11$ & $0.69-0.94$ & $1.36^{\mathrm{b}} \pm 0.18$ & $1.15-1.57$ \\
\hline & Total & $0.90 \pm 0.12$ & $0.69-1.07$ & $1.49 \pm 0.21$ & $1.15-1.79$ \\
\hline \multirow{4}{*}{$4+$} & Females & $0.92^{\mathrm{a}} \pm 0.08$ & $0.84-0.99$ & $1.57^{\mathrm{a}} \pm 0.10$ & $1.48-1.66$ \\
\hline & Males & $0.94^{\mathrm{a}} \pm 0.08$ & $0.85-1.05$ & $1.59^{a} \pm 0.14$ & $1.42-1.76$ \\
\hline & Juveniles & $0.95^{\mathrm{b}} \pm 0.06$ & $0.70-0.90$ & $1.41^{\mathrm{b}} \pm 0.10$ & $1.17-1.50$ \\
\hline & Total & $0.90 \pm 0.08$ & $0.70-1.05$ & $1.51 \pm 0.14$ & $1.17-1.76$ \\
\hline \multirow{4}{*}{$5+$} & Females & $0.96^{\mathrm{a}} \pm 0.10$ & $0.88-1.17$ & $1.68^{\mathrm{a}} \pm 0.18$ & $1.50-2.03$ \\
\hline & Males & $0.98^{b} \pm 0.19$ & $0.72-1.41$ & $1.66^{\mathrm{a}} \pm 0.32$ & $1.25-2.40$ \\
\hline & Juveniles & - & - & - & - \\
\hline & Total & $0.98 \pm 0.15$ & $0.72-1.41$ & $1.67 \pm 0.27$ & $1.25-2.40$ \\
\hline \multirow{4}{*}{$6+$} & Females & $1.14^{\mathrm{a}} \pm 0.11$ & $1.00-1.35$ & $1.97^{\mathrm{a}} \pm 0.19$ & $1.70-2.31$ \\
\hline & Males & $0.98^{b} \pm 0.19$ & $0.74-1.47$ & $1.70^{b} \pm 0.32$ & $1.29-2.50$ \\
\hline & Juveniles & - & - & - & - \\
\hline & Total & $1.04 \pm 0.18$ & $0.74-1.47$ & $1.80 \pm 0.30$ & $1.29-2.50$ \\
\hline \multirow{4}{*}{$7+$} & Females & $0.96^{\mathrm{a}} \pm 0.12$ & $0.79-1.11$ & $1.68^{\mathrm{a}} \pm 0.12$ & $1.38-1.93$ \\
\hline & Males & $0.97^{a} \pm 0.18$ & $0.76-1.24$ & $1.68^{a} \pm 0.18$ & $1.31-2.17$ \\
\hline & Juveniles & $096+015$ & $07 \overline{-1} 24$ & $169+026$ & $13 \overline{-2} 17$ \\
\hline & 10tar & $0.50=0.18$ & $0.10-1.24$ & $1.07+0.20$ & $1.51-2.1$ \\
\hline \multirow{4}{*}{$8+$} & Females & $1.00^{\mathrm{a}} \pm 0.20$ & $0.69-1.37$ & $1.78^{a} \pm 0.35$ & $1.24-2.43$ \\
\hline & Males & $1.11^{\mathrm{b}} \pm 0.10$ & $0.89-1.20$ & $1.96^{b} \pm 0.18$ & $1.57-2.12$ \\
\hline & Juveniles & $104+018$ & $060-137$ & $184+032$ & \\
\hline & Total & $1.04 \pm 0.18$ & $0.69-1.37$ & $1.84 \pm 0.32$ & $1.57-2.43$ \\
\hline \multirow{4}{*}{$9+$} & Females & $0.88^{a} \pm 0.13$ & $0.74-1.36$ & $1.57^{\mathrm{a}} \pm 0.24$ & $1.32-2.46$ \\
\hline & Males & $0.84^{b} \pm 0.16$ & $0.69-1.21$ & $1.49^{b} \pm 0.29$ & $1.24-2.17$ \\
\hline & Juveniles & - & - & - & - \\
\hline & Total & $0.87 \pm 0.14$ & $0.69-1.36$ & $1.56 \pm 0.25$ & $1.24-2.46$ \\
\hline \multirow{4}{*}{$10+$} & Females & $0.87 \pm 0.15$ & $0.74-1.42$ & $1.58 \pm 0.28$ & $1.34-2.60$ \\
\hline & Males & 0.91 & $0.91-0.91$ & 1.64 & $1.64-1.64$ \\
\hline & Juveniles & - & - & - & \\
\hline & Total & $0.87 \pm 0.15$ & $0.74-1.42$ & $1.58 \pm 0.28$ & $1.34-2.60$ \\
\hline \multirow{4}{*}{$11+$} & Females & $0.87 \pm 0.14$ & $0.73-1.43$ & $1.57 \pm 0.25$ & $1.34-2.60$ \\
\hline & Males & 0.95 & $0.95-0.95$ & 1.73 & $1.73-1.73$ \\
\hline & Juveniles & - & - & - & - \\
\hline & Total & $0.87 \pm 0.14$ & $0.73-1.43$ & $1.58-0.25$ & $1.34-2.60$ \\
\hline
\end{tabular}

Values with the same superscript are significantly different $(P>0.05)$; $\mathrm{SD}=$ standard deviation. 
females and 183-358 mm for males and were greater than the values reported by Pęczalska and Kraczkiewicz (1973) and Raczyński and Keszka (2007), but not different from the values obtained for the fish from other water reservoirs in Poland (Wajdowicz 1974, Bontemps 1971). The differences were observed in the length of females and males. Females had greater length, individual mass and age than males.

Because of high hydrological and environmental diversity of the rivers and other water bodies, considerable variation was noted in the rate of vimba growth (Table 4). According to Bontemps (1971) this phenomenon is related to many factors, mainly the temperature in a given year and quantity and quality of food. The highest growth rate was reported for the populations from the Dniester and Dnieper rivers (Volskis et al. 1970), while the growth rate of the population from the Odra River estuary in the first years of age was better than in the other water bodies in Poland (Bontemps 1971, Pęczalska and Kraczkiewicz 1973) and in the Czech Republic (Bontemps 1963, Lusk et al. 2005) (Table 4). the relatively worse state of water in the middle and lower Odra River as well as the presence of genetically foreign vimba population from the Rega River could disturb the integrity of the Odra River population (Witkowski et al. 2004).

In conclusion, we would like to emphasize that the restitution project of the vimba population in the Odra River estuary has been successful in terms of the increase in the number of the fish caught. Based on the biomass of vimba caught during the presently reported study $(60 \mathrm{~kg})$ and the number of fishermen teams working in the Odra River estuary, the total biomass of vimba caught in a year can be estimated for 4-6 tons. The partial success of the restitution efforts is also indicated by the biological and population traits of the species not differing from those reported by other authors and determined in the past based on abundant and stable populations. Unfortunately, the results of a genetic study on the vimba from Poland proved the homogeneity of the stocking material. It should be emphasized that populations developed from such material are, as a rule, genetically unstable, not abun-

The length growth rate [cm] of Vimba vimba from different regions of central Europe

Table 4

\begin{tabular}{|c|c|c|c|c|c|c|c|c|c|c|c|}
\hline \multirow{2}{*}{ Water basin } & \multirow{2}{*}{ Author } & \multicolumn{10}{|c|}{ Age group } \\
\hline & & I & II & III & IV & $\mathrm{V}$ & VI & VII & VIII & IX & $\mathrm{X}$ \\
\hline Vltava River (Czech Rep.) & Bontemps (1963) & 5.3 & 8.8 & 12.0 & 15.4 & 18.4 & 21.6 & - & - & - & - \\
\hline $\begin{array}{l}\text { Danube drainage basin } \\
\text { (Czech Rep.) }\end{array}$ & Bontemps (1963) & 6.0 & 9.9 & 13.1 & 16.6 & 19.8 & 一 & 一 & - & - & - \\
\hline Dyje River (Czech Rep.) & Lusk et al. (2005) & 7.1 & 11.5 & 14.8 & 17.8 & 20.2 & 23.4 & 25.4 & 27.4 & 28.5 & 30.0 \\
\hline Dubysa River (Lithuania) & Kesminas et al. (1999) & - & - & - & 21.0 & 23.5 & 26.3 & 28.5 & 32.0 & - & - \\
\hline Sventoji River(Lithuania) & Kesminas et al. (1999) & - & - & - & - & - & 27.7 & 31.8 & 36.0 & - & - \\
\hline Nemunas River (Lithuania) & Kesminas et al. (1999) & - & - & - & 21.0 & 23.7 & 26.6 & 28.4 & 29.8 & - & - \\
\hline Nemunas River (Lithuania) & Volskis et al. (1970) & 3.4 & 6.9 & 15.0 & 19.6 & 22.1 & - & - & - & - & - \\
\hline Nemunas River (Belarus) & Volskis et al. (1970) & 6.3 & 12.3 & 17.9 & 22.7 & 26.6 & - & - & - & - & - \\
\hline Dneper River (Ukraine) & Volskis et al. (1970) & 7.5 & 15.0 & 20.4 & 26.3 & 28.3 & - & - & - & - & - \\
\hline Dnester River (Ukraine) & Volskis et al. (1970) & 14.5 & 20.0 & 23.0 & 26.1 & 29.4 & - & - & - & - & - \\
\hline Vistula River (Poland) & Bontemps (1960) & 5.1 & 8.8 & 13.5 & 18.1 & 22.4 & 26.2 & 29.7 & 31.4 & - & - \\
\hline Szczecin Lagoon (Poland) & $\begin{array}{l}\text { Pęczalska and } \\
\text { Kraczkiewicz (1973) }\end{array}$ & 8.5 & 11.4 & 13.5 & 15.4 & 18.6 & 20.5 & 23.3 & 26.0 & 29.0 & 31.3 \\
\hline Odra River estuary (Poland) & Presently reported study & 9.5 & 11.8 & 14.2 & 16.4 & 18.8 & 21.0 & 23.0 & 25.3 & 27.5 & 29.3 \\
\hline
\end{tabular}

An important parameter reflecting the type of environmental conditions is the condition of the fish. For the vimba caught in the Odra River estuary the mean values of Fulton and Le Cren condition coefficients were 0.93 and 1.64, respectively, while the ranges of their variation were $0.69-1.47$ and 1.15-2.60. Only Wajdowicz (1974) reported the Fulton coefficient values for vimba of subsequent age groups from the Czarna Orawa River. According to the above author, the condition of spawning vimba from the Czarna Orawa River was higher than that from the Odra River. Such differences were not only a consequence of environmental conditions. The data on reproduction and growth of natural populations of vimba from the 1950s (Pliszka 1953) have revealed considerable differences in the ecology of spawning of the vimba from the regions of Sub-Carpathian and (Polish) West Pomerania, which could influence the conditions of the fish. Moreover, dant. Moreover, the vimba caught commercially has still been considered a by-catch (Kempter 2010). It is important that apart from the efforts related to stocking of the Odra River estuary, some other measures should be taken, aimed at a rational use of vimba resources, such as introduction of the protective season in seawater area covering the Szczecin Lagoon and Lake Dąbie. These measures along with proper management of the Odra River drainage (regulation of watercourses and reconstruction of the spawning sites) should bring fully successful restitution of this species of fish in the area.

\section{ACKNOWLEDGEMENTS}

The authors would like to thank $\mathrm{Mr}$ Pawel Dawidowski a fisherman from the Odra River estuary for providing vimba from his commercial catches and for his kind assistance during the laboratory examinations. 


\section{REFERENCES}

Bolger T., Connolly P.L. 1989. The selection of suitable indices for the measurement and analysis of fish condition. Journal of Fish Biology 34 (2): 171-182. DOI: $10.1111 /$ j.1095-8649.1989.tb03300.x

Bontemps S. 1963. The growth of east-European bream, Vimba vimba (Linnaeus) in the Labe and Danube river drainages. Věstník Československé Společnosti Zoologické 27 (2): 125-129.

Bontemps S. 1955. Połowy certy w Polsce. [Vimba catches in Poland.] Gospodarka Rybna 9 (9): 11-13. [In Polish.]

Bontemps S. 1960. Ocena stanu pogłowia certy z systemu rzeki Wisły. [Estimation of the current status of vimba resources from Wisła River system.] Roczniki Nauk Rolniczych B 75: 179-211. [In Polish.]

Bontemps S. 1971. Certa. [Vimba.] PWRiL, Warszawa. [In Polish.]

Chelkowski Z., Filipiak J. 2000. Osteological characteristics of fish remains from early medieval town of Wolin (site 1, Pit. 6). Folia Universitatis Agriculturae Stetinensis 27 (214): 55-67.

Heese T. 2000. Certa (Vimba vimba (L.)). [Vimba (Vimba vimba (L.)).] Pp. 266-272. In: Brylińska M. (ed.) Ryby słodkowodne Polski. [Freshwater fishes of Poland.] PWN, Warszawa. [In Polish.]

Kempter J. 2010. Zmienność genetyczna wybranych populacji certy Vimba vimba (L.) na podstawie analizy molekularnej genu cytochromu b w aspekcie ochrony gatunku. [Genetic variability of selected populations of vimba, Vimba vimba (L.), based on molecular analysis of the cytochrome B gene-in relation to preservation of the species.] Wydawnictwo Uczelniane ZUT w Szczecinie. [In Polish.]

Kesminas V., Virbickas T., Stakenas S. 1999. The state and morphological characteristics of vimba (Vimba vimba L.) subpopulation in the middle Nemunas. Acta Zoologica Lituanica 9 (1): 147-154.

Kleszcz M., Matura M., Witkowski A. 2001. Certa Vimba vimba (L.) - udana próba produkcji materiału zarybieniowego i restytucji w środkowym dorzeczu Odry. [Vimba Vimba vimba (L.) - a successful test of stock material production and restitution in middle part of Odra drainage.] Komunikaty Rybackie 1 (60): 15-17. [In Polish.]

Lelek A. 1987. Threatened fishes of Europe. Vol. 9. The freshwater fishes of Europe. AULA- Verlag, Wiesbaden.

Lusk S., Lusková V., Halačka K., Šlechtová V., Šlechta V. 2005. Characteristics of remnant Vimba vimba population in the upper part of the Dyje River. Folia Zoologica 54 (4): 389-404.

Makowiecki D. 2003. Historia ryb i rybołówstwa w holocenie na Niżu Polskim w świetle badań archeoichtiologicznych. [History of fishes and fishing in Holocen on Polish Lowland in the light of archeoichthyological studies.] Instytut Archeologii i Etnologii PAN, Oddział w Poznaniu. [In Polish.]

Pęczalska A., Kraczkiewicz W. 1973. Wybrane zagadnienia $\mathrm{z}$ biologii certy (Vimba vimba (L.) z Zalewu Wiślanego. [Some aspects of biology of vimba (Vimba vimba (L.) from Wisła Lagoon.] Prace MIR (Gdynia) A 17: 129-144. [In Polish.]

Pliszka F. 1953. Rozród i rozwój certy (Vimba vimba L.). [The Spawning and early development of vimba (Vimba vimba L.] Polskie Archiwum Hydrobiologii 1: 137-163.
Psuty-Lipska I., Garbacik-Wesołowska A. 1998. Species composition and fish distribution in the Pomerania Bay and Szczecin Lagoon. Bulletin of the Sea Fisheries Institute 3 (145): 3-20.

Raczyński M., Keszka S. 2007. Ocena aktualnego stanu i biologiczna charakterystyka populacji wędrownej formy certy (Vimba vimba (L.)) w ujściu Odry i Zalewie Szczecińskim w obliczu restytucji gatunku. [Estimation of the current status and biological characteristics of the anadromous form of vimba (Vimba vimba (L.)) in the Odra River mouth and the Szczecin Lagoon in connection with a restitution program.] Roczniki Naukowe Polskiego Związku Wędkarskiego 20: 137-151. [In Polish.]

Repecka R. 2003. Changes in biological indices and abundance of salmon, sea trout, smelt, vimba and twaite shad in the coastal zone of the Baltic sea and the Curonian Lagoon at the begining of spawning migration. Acta Zoologica Lituanica 13 (2): 195-216.

Ritterbusch-Nauwerck B. 1995. Condition or corpulence, fitness or fatness: a discussion of terms. Archiv für Hydrobiologie, Special Issues in Advanced Limnology 46: 109-112.

Sokal R.R., Rohlf F.J. 1995. Biometry: the principles and practice of statistics in biological research. 3rd edn. W.H. Freeman and Company, New York.

Stanisz A. 2000. Przystępny kurs statystyki z wykorzystaniem programu STATISTICA PL na przykładach z medycyny. [An easy course in statistics using the Statistica ${ }^{\mathbb{R}} \mathrm{PL}$ package based on medical examples]. Vol. 2. [In Polish.]

Suhanova E.R., Erm V., Spiryna L.I., Volskis R. (eds.) 1970. Biologija i promyslovoe značenie rybcov (Vimba) Evropy. [Biology and commercial importance of vimba (Vimba) of Europe.] Mintis, Vilnius. [In Russian.]

Sych R. (ed.) 1996. O projekcie restytucji ryb wędrownych $\mathrm{w}$ Polsce. [About restitution project of migratory fishes in Poland.] Zoologica Poloniae 41 (Suppl.): 47-59. [In Polish.]

Szypuła J., Rybczyk A. 2001. Age, growth, and condition of perch in the Odra estuary (1991-1999). Folia Universitatis Agriculturae Stetinensis 218 (28): 151-164.

Trzebiatowski R., Narożański A. 1973. A contribution to studies on the biology of vimba - Vimba vimba (L.) from the Rega River. Acta Ichthyologica et Piscatoria 3 (2): 17-27.

Volskis R., Moros W.N., Suhanowa E.R. 1970. Nierest. [Spawning time.] Pp. 105-133. In: Suhanova E.R., Erm V., Spiryna L.I., Volskis R. (eds.) Biologija i promyslovoe značenie Rybcov (Vimba) Evropy. [Biology and commercial importance of vimba (Vimba) of Europe.] Mintis, Vilnius. [In Russian.]

Wajdowicz Z. 1974. Charakterystyka stada tarłowego certy z Czarnej Orawy. [Characteristics of the spawning broodstock of vimba from the Czarna Orawa River]. Acta Hydrobiologica 16: 221-238. [In Polish.]

Wiśniewolski W. 1987. Gospodarcze połowy ryb w Wiśle, Odrze i Warcie w latach 1953-1978. [Commercial catches of fishes in the Vistula, Odra, and Warta rivers in the years 1953-1978.] Roczniki Nauk Rolniczych 101 (2): 71-114. [In Polish.]

Wiśniewolski W., Buras P., Ligęza J., Kleszcz M., Witkowski A. 2008. Wędrowna forma certy - Vimba vimba (L.) 
w systemie rzek Wisła i San - stan historyczny i obecny. [The migratory form of the vimba-Vimba vimba (L.) in the Vistula and San river system-history and present state] Pp. 7-22. In: Kukuła K., Rak J., Czopek S. (eds.) Walory przyrodniczo-historyczne Pogórzy. [Natural and historical value of foothills] Wydawnictwo Uniwersytetu Rzeszowskiego i Politechniki Rzeszowskiej. [In Polish.]

Witkowski A., Kleszez M., Heese T., Martyniak A. 2004. Certa (Vimba vimba) dorzecza Odry: historia, stan aktualny i perspektywy. [Vimba (Vimba vimba) of Odra drainage: history, current status and perspectives.] Archiwum Rybactwa Polskiego 12 (Suppl. 2): 103-115. [In Polish.]
Witkowski A., Kotusz J., Przybylski M. 2009. Stopień zagrożenia słodkowodnej ichtiofauny Polski: czerwona lista minogów i ryb - stan 2009. [The degree of threat to the freshwater ichthyofauna of Poland: Red list of fishes and lampreys - situation in 2009.] Chrońmy Przyrodę Ojczystą 65 (1): 33-52. [In Polish.]

Received: 14 May 2011

Accepted: 22 September 2011

Published electronically: 30 September 2011 